\title{
CO-DETERMINATION POLITICS ON COMMERCIAL COMPANIES IN ALBANIA: A COMPARATIVE STUDY
}

Blerta Aliu, European University of Tirana, baliu @uet.edu.al

This paper focuses on understanding the role that stakeholders, especially, employees have in a company and corporate governance implications. Currently, human capital, embodied to employees, has become very fast the most important source of corporate value. This study makes an overview of the current situation in Albania, analyzing legal provisions and relevant international literature on this issue. The trends of the result for decision-making in the Albanian companies show a low level of participation of stakeholders, particularly employees. This study is based on a comparison between American common law system, supporters of the shareholders and the German civil law system, supportive of stakeholders. Here, is apparently stated the need to embrace the second system. Recent developments of American companies and the financial crisis are reasons which brought us to this conclusion. The German practice also, shows clearly that corporate social responsibility is the key to success, if it adapts to different historical, legal and cultural contexts.

JEL Classification Numbers: J54, M14, DOI: 10.12955/cbup.2013.20

Keywords: co-determination procedures, employee legal guarantees, corporate social responsibility

\section{Introduction}

The scope of this paper is to analyze the commercial legal framework in Albania, with focus on governing trends of commercial companies in Albanian. The emphasis is on the role of workers as stakeholders. The comparative analysis of two representative models of corporate governance helps to shed light on the challenges encountered in the Albanian practice.

Such a research on 'co-determination' of companies has a growing importance. Baums (1997) points out that the internationalization of capital investments leads private investors to question how their interests are protected abroad. In this context, global investors are interested in learning about all kinds of corporate governance features, such as voting rights of shareholders, takeover and insider regulations, transferability of shares, protection of minority rights and protection of stakeholders. The literature on corporate governance shows that the system affects the main issues. Common law countries have a better minority shareholder protection than civil law countries. On the other side, civil law countries have better stakeholder protection than common law countries.

\section{A Brief Overview}

The German system is rooted in 1602, when the board structure in Germany was a one-tier board model (Hopt \& Leyens, 2004). It experienced some changes with the introduction of a committee of 
nine in 1623, which can be described as an early form of a modern supervisory board. Today, business relationships have inherited the characteristics of the German supervisory board and consequently this raises some serious concerns on with regard to the independence, objectivity, and conflicts of interests. Despite this, Hopt and Leyens (2004) note that German peculiarity is its strong labor co-determination. According to Gorezi (2011), the European approach, typically the German one, is characterized by a concentration of bank ownership and their participation, as creditors, in the decision making of the company.

On the other way, the American Approach is characterized by a deeply fragmented ownership, where the Chief Executive Officers are crucial. So, discussions attached to the problem of "representation" are executive compensation issues, as Bebchuk and Fried (2003) note.

Keay (2010) analyzes the differences between shareholder and stakeholder theory and observes that there is shift from the shareholder approach towards the stakeholder approach in the Anglo-American jurisdictions. He refers to Bainbridge (2003) who has divided the shareholder theory into two limbs: a) the objective of the company to maximize shareholder wealth and; b) the right of the shareholders to have the ultimate control of the company. Referring to Freeman and Keay (2010) brings the argument on stakeholder theory as an end and not as a mean to an end. The theory advocates that the duty of the managers of companies is to create optimal value for all social actors and thus creating a balance.

\section{Analysis on Shareholder Rights: A Comparative Aproach}

Shareholders' rights and their activity in the U.S. have emerged as a need to be protected from conflicts of interests with and in the Executive Board. Gorezi (2011) notes that in general, American corporate law gives broad discretion to managers for business strategies and gives them the right to sit on the Board of Directors, to oversee themselves. Theoretically, there are defined procedural mechanisms in cases of breaching of duty of loyalty, but in practice courts are inclined to support managers when they take risks. Therefore there is a need for a standardized measure to judge the level of care of managers. Executive compensation schemes are a tool to determine managers' interests in line with those of company. However, Cioffi and Berle (2005) considered the above mentioned, as faulty mechanisms, especially in transitional contexts where forms of fraud and abuse are more numerous.

Transition economies should adapt the German-type system with strong universal banks and a stable core of large shareholders which are exercising effective control on management (Nunnenkamp, 1995). According to this, Pajuste (2001) gives a view on the development of market capitalization in Central and East Europe. The characteristics of privatization method in each of these countries reflect the nature of their development. Most of these countries have a tendency of ownership concentration. According to the study made by Pajuste (1994-2001) in CEE transitional countries, the typical example on ownership concentration is, the largest owner is a corporation and the second largest is an insider (CEO or manager), who owns a direct or indirect stake in the above mentioned corporation.

Systems with significant problems in conceptualizing governing and transparency issues, face difficulties in developing equity markets. The implementation of the principles of the OECD (2004) about transparency and accountability gets a different meaning in the Albanian companies. It is worth mentioning the universal principle, that the effectiveness of legal rules relays in their capacity to fit with a given specific context. Law's coherence and their applicability in practice are a major challenge. As Nunnenkamp (1995) underlines, the appropriateness of existing models for transition 
economies depend on country specific circumstances and the objectives to be achieved during the process of transformation.

The Albanian company legislature has its roots in 1932, with the first Commercial Code serving as a coherent legal framework at that time. Since ' 40 -s until ' 90 -s, the Albanian system of law prohibited the free and private initiative. With the collapse of the communist system in 1991, the Albanian Parliament drafted the Law no. 7512 dated 10.08.1991 "On the sanction and protection of private property and free initiative, independent private activities and privatization". In 1992, the Parliament approved the Law 7638 "On Companies" and then in 2008, it drafted the Law which currently is in force, and which is in compliance with the principles of international trade.

The Law no. 9901, date 14.07.2008 "On entrepreneurs and Commercial companies" gives space to the company founders, to choose between one or two tier board model. The Albanian case required to take in analyses the provisions about shareholders assembly, manager's rights and stakeholder's incorporation. The process of privatization in Albania was accompanied by establishment of companies characterized by a concentration of ownership (Stillo \& Llaçi, 2008). The lack of effectiveness in the relationship between majority and minority shareholders, is one of the biggest problems of this framework. The question raised here is, why do corporate owners choose to concentrate their power? According to Pajuste (2001) one of the reasons is related to the fact that large shareholders want to enjoy benefits of control at the expense of minority shareholders. On the other side, gaps in the regulatory framework and poor enforcement mechanisms lead to the situation where only the controlling owners have influence over the managers and company policy.

According to National Register (NRC, 2013) in Albania, approximately 90\% of albanian companies are limited liability companies and $10 \%$ are joint ventures and other forms. This is a plain measurement, which shows that expectations for compliance with corporate governance principles, find a solid terrain in small and medium enterprises, namely SME-s that have a crucial role in economy. According to legal provisions, limited liability companies, are characterized by "intuitu personae" or otherwise known as trust between company co founders. It clearly shows the structure of partnership, based fundamentally on family or friendship relations. These companies are closed to public investment.

Typical American or German corporation focus on discussions such as agency, executive compensation, principles of loyalty or stakeholders' role. Albanian trading companies have already begun to become familiar with such concepts. As Gorezi and Kononov (2013) point out, international problems affect a number of issues. Firstly, the sterilization of the right to vote, which relates to the question of who is the real voter: stock holders, recent investors, or holders of authorizations. Secondly, the issue of the dissemination of information through "push or pull" systems and last but not least issues on insufficient timeframes and legal barriers on shareholder activism.

Albanian political and financial rights of partners or shareholders, settle the core of this discussion, the right of control over decision-taking. The right to vote, as sanctioned in Article 140 by Law no.9901, is exercised into the General Assembly of Partners / Shareholders. Malltezi (2011) stresses out the protection of minority shareholders in Albania, reflected in the Law 9901, "On Entrepreneurs and commercial companies". They have the right to raise issues in the agenda of the Meetings of General Assembly of Shareholders and the right of derivative lawsuits, which can take at least $5 \%$ of shareholders. The principles on duty of loyalty, section 4, Article 15, establishes that "individuals responsible for the management of the company, should inform all partners or shareholders for the 
performance of activities, at their request, and shall make available the annual accounts". These include accounts on consolidated reports on conditions and operating performance of the company, reports on the organs or the independent auditors as well as any other internal document, except those specified in Article 18 of the Law.

In cases when, individuals responsible for the management of the company do not provide the required information, the partners, members or shareholders concerned, within 30 days after the refusal, should make a request to the competent court to execute their request. Failure to provide the information required within 7 days by the date of the receipt of the request, is estimated as rejection. The presence of deadlines indicates that the right to information is not unlimited in time, but it must be carried within a certain timeframe and non-compliance with deadlines leads to violation of the right to be informed.

In this context, Gorezi and Kononov (2013) argues that regarding the absorption of information from the shareholders or partners, the Albanian system mandates a pushing system that can complemented by pull system forms. They bring arguments about economic costs or shareholders' rational apathy; over each of two forms of information "push or pull". According to a study, made in 1997 in Europe, public companies were still to a large extent dominated by large shareholders, groups of companies, families or the state (Baums on OECD, 2000). The report also found that a fundamental change is under way in Europe today. Stakes of block holders, especially of corporations and founding family block holders, are fading, state-owned businesses have been privatized to a large extent, and the share of institutional investors, domestic and foreign, is increasing. Baums raises the question: What are the main effects of these developments on the shareholders' meeting? Will these developments change the role and the format of the shareholders' meeting?

Therefore, he concludes that, depending on the structure and dispersion of shareholdings, control in firms with large block holders will not necessarily be exercised via formal channel of decisions taken by shareholders in general meetings. Especially, in the case of one dominant shareholder, alongside with a minority of small shareholders, the informal influence of the dominant shareholder on management will be relevant. So, the shareholders' meeting may be reduced to taking few formal decisions (Baums, 2000). If we refer to the quorum needed in shareholder meetings, according to Baums, Mediterranean countries have substantial limits and respective problems, leading to the practice of a second or a third meeting, where no quorum is applicable.

\section{Implications on Corporate Social Responsibility}

The analysis of corporate governance often leads to the discussion on the level and modalities of influencing decision-making by stakeholders (Freeman, 1994). However this is not present in the academic literature in Albania. The term corporate social responsibility is mainly implemented by companies or large corporations. However, due to the fact that such big companies and large corporations are very few in Albania, it is important to apply such practices in all types of public and private enterprises, including small and medium enterprises, since these last ones are widespread in country.

Institutional provisions have been created to protect interests of creditors, employees or community at large, which are considered as important groups into company's structure. However there are noticed difficulties in their implementation because in order to be successfully implemented such provisions should be part of the legal culture. The involvement of employees in governmental institutions reflects 
social culture in the context of German companies. Hopt and Leyens (2004) state that corporations with over 2000 employees appoint a number of representatives equal to the number of shareholders in the Supervisory Board, while in corporations with 500-2000 employees, the number of their representatives is at least $1 / 3$ of the members of the Supervisory Board. This policy became an essential symbol of the country's economic policy and allows employees, through rights to information, consultation, co-determination and their authority to seek compensation, for the damage that may be caused to them by the bad decisions taken by their executives.

While U.S. and Germany were placing the first stones towards corporate government principles, Albania challenged the concept of private property (during communism), enshrined later in the 1990s. Institutional indicators, legal environment and noncompliance rates are typical and places as Albania have major difficulties. Pistor (2011), referring to the study on the characteristics of legal change in countries with transitional economies categorizes Albania as a country with a low level of protection of stakeholders, like all transition countries despite differences depending on certain periods.

The Law no. 9901 provides in Articles 19-21 the dispositions for the creation of Employee Councils into companies with more than 50 employees and a maximum term of 5 years. Article 20 provides the rights and obligations of the Council of Employees, by determining that costs are covered by the company; this provision allows for assumptions such as: How can directors create long term values without increasing the cost of the company? Do shareholders have to increase costs for a proper functioning of workers council? The answer is simple: so far there have been no practical cases on these issues.

According to the recent study of Bello (2013) in Albania, the banking system reflects the trends of social responsibility and states that "when we refer to the banking market, two components have influenced the development of corporate social responsibility practices. First, the recognition and international awareness regarding these practices has played a key role in raising awareness in Albania and secondly, the adequacy of the Corporate Social Responsibility policy implemented by "parent" banks who have subsidiaries in Albania. So the German legal heritage comes through globalization of markets and international companies, applying similar practices in countries that perceive these techniques as innovative. Finally, as Keay (2010) underlines, the view of US constituency statutes teaches us that there is no "quick fix" in corporate law, to ensure the interests of stakeholders. He notes that, if there is to be a shift of American system toward stakeholders it must involve more than just legislative directives and it will certainly take time. It will certainly take time for Albanian companies to move towards the innovative management and stakeholder protection.

\section{Conclusion}

Corporate governance system interacts with a variety of legal components such as labor laws, bankruptcy laws, environmental protection, etc. In this paper we mentioned some problems characterizing Albania, inherited by a political system of power concentration in the hands of one person. This feature is reflected in trade relations between persons. So, we have ownership concentration of a partner /shareholder who decides everything about his business strategies. This reflects handicaps in market economy development, especially in terms of security market and lack of: transparency, information principles and continuous publication. Also, there is little or no room for other actors. Despite its coherent legal system, designed in accordance with the principles of the OECD and European directives, Albania accords little legal spaces that can be used to avoid the legal 
minimum for employees. Also, the lack of case law shows easily an embryonic stage of respect for human rights by corporations. Finally, strengthening the role of banks in our system as a German trend might be a good option.

\section{References}

Baums, T. (2000). General Meetings in Listed Companies - New Challenges and Opportunities. Retrieved from Institute for Banking Law, Goethe Universitat in Frankfurt, March 26, 2013, from http://www.oecd.org/daf/ca/corporategovernanceprinciples/1931816.pdf

Bello, H. (2012). Audition of Corporate Social Responsibility in the Banking system of Albania. The Banker Magazine, Vol. 6, p. 28-29. Retrieved April 8, 2013 from http://www.aab.al/bankieri/6/Bankieri_6_alb.pdf3

Cioffi, W. J. \& Berle, A. (2005). Corporate Governance Reform, Regulatory Politics, and the Foundations of Finance Capitalism, in the United States and Germany. The Center for Law and Economic Studies, Vol. 304, p. 1-82. Retrieved March 13, 2013, from http://ssrn.com/abstract=830065

Freeman, E. (1994). The Politics of Stakeholder Theory: Some Future Directions. Business Ethics Quarterly, 4 (4), p. 4.

Gorezi, A. \& Kononov, O. (in press). The Directive on Shareholder Rights; A Critical View. Berkeley Business Law Journal.

Gorezi, A. (2011). Shareholder Rights, Executive Compensation and Shareholder Protection: A Comparative Overview of United States of America and chosen European Union Jurisdictions. Available at CEU, Electronic Theses and Dissertations Collection, (p. 46-72).

Keay, A. (2010). Moving towards stakeholderism? Constituency statutes, enlightened shareholder value, and all that: Much Ado About Little? Available at Centre for Business Law and Practice School of Law, University of Leeds. (p. 1-57). Retrieved from http://ssrn.com/abstract=1530990

Hopt, J. K. \& Leyens, C. P. (2004). Board Models in Europe. Recent Developments of Internal Corporate Governance Structures in Germany, The United Kingdom, France and Italy. ECGI, Vol. 18, p. 5-30. Retrieved from http://ssrn.com/abstract=487944T

Malltezi, A. (2011). E Drejta Shqiptare e Shoqerive Tregtare [Albanian Commercial Law]. (Vol. 1, p. 126-154). Tirane, Albania: Media Print.

Ministry Of Economy, Trade and Energy of Albania. (2012). Law No.9723, date 03.05.2007, Për Qendrën Kombëtare të Registrimit [On the National Registration Center]. Retrieved May 18, 2013, from http://80.78.70.231/pls/kuv/f?p=201:Ligj:9723:03.05.2007

Ministry Of Economy, Trade and Energy of Albania. (2011). Law No. 9901, date 14.07.2008, Për tregtarët dhe Shoqëritë Trgetare [On entrepreneurs and Commercial companies]. Retrieved May 21, 2013 from http://80.78.70.231/pls/kuv/f?p=201:Ligj:9901:14.04.2008

Ministry Of Economy, Trade and Energy of Albania. (2008). Law No. 7512, date 10.08.1991, Për sanksionimin dhe mbrojtjen e pronës private dhe iniciativës së lirë, veprimtarisë private dhe privatizimeve [On the sanction and protection of private property and free initiative, independent 
private activities and privatization]. Retrieved May 19, 2013, from

http://80.78.70.231/pls/kuv/f?p=201:Ligj:7512:10.08.1991

Ministry Of Economy, Trade and Energy of Albania. (2008). Law No.7638, date 19.11.1992, Pwr shoqwritw tregtare [On Commercial Companies]. Retrieved May 23, 2013, from http://80.78.70.231/pls/kuv/f?p=201:Ligj:7638:19.11.1992

Nunnenkamp, P. (1995). The German model of corporate governance: Basic features, critical issues, and applicability to transition economies. ECONSTOR, Vol.7, 5-18. Retrieved from http://hdl.handle.net/10419/855

OECD. (2004). OECD Principles of Corporate Governance. Retrieved April 29, 2013, from http://www.oecd.org/corporate/ca/corporategovernanceprinciples/31557724.pdf

Pajuste, A. (2002). Corporate Governance and Stock Market Performance in Central and Eastern Europe: A study of nine countries, 1994-2001. Centre for the Study of Economic Social Change in Europe, Vol. 22, p. 2-33. Retrieved from http://ssrn.com/abstract=310419

Stillo, S. \& Laci, S. (2008). Corporate governance in transition economies. Economies and Business Magazine, Vol. 1, p. 117-128. 